\title{
Correction to: Downregulation of IncRNA ZNF582-AS1 due to DNA hypermethylation promotes clear cell renal cell carcinoma growth and metastasis by regulating the $\mathrm{N}(6)$-methyladenosine modification of MT- RNR1
}

Wuping Yang ${ }^{1,2,3,4}$, Kenan Zhang 1,2,3,4 Lei Li ${ }^{1,2,3,4}$, Yawei Xu' ${ }^{1,2,3,4}$, Kaifang Ma ${ }^{1,2,3,4}$, Haibiao Xie ${ }^{1,2,3,4}$, Jingcheng Zhou ${ }^{1,2,3,4}$, Lin Cai ${ }^{1,2,3,4}$, Yanqing Gong ${ }^{1,2,3,4^{*}}$ and Kan Gong ${ }^{1,2,3,4^{*}}$

Correction to: J Exp Clin Cancer Res 40, 92 (2021) https://doi.org/10.1186/s13046-021-01889-8

Following publication of the original article [1], the authors identified a minor error in image-typesetting in Fig. 4, specifically:

- Figure 4j: the first mouse lung of ZNF582-AS1 OE group has been replaced with the correct image

The corrected figure is given below. The correction does not have any effect on the results or conclusions of the paper. The original article has been corrected.

The original article can be found online at https://doi.org/10.1186/s13046021-01889-8.

*Correspondence: yqgong@bjmu.edu.cn; gongkan_pku@126.com

'Department of Urology, Peking University First Hospital, No. 8, Xishiku Street, Xicheng District, Beijing 100034, China

Full list of author information is available at the end of the article

(c) The Author(s). 2021 Open Access This article is licensed under a Creative Commons Attribution 4.0 International License, which permits use, sharing, adaptation, distribution and reproduction in any medium or format, as long as you give appropriate credit to the original author(s) and the source, provide a link to the Creative Commons licence, and indicate if changes were made. The images or other third party material in this article are included in the article's Creative Commons licence, unless indicated otherwise in a credit line to the material. If material is not included in the article's Creative Commons licence and your intended use is not permitted by statutory regulation or exceeds the permitted use, you will need to obtain permission directly from the copyright holder. To view a copy of this licence, visit http://creativecommons.org/licenses/by/4.0/ The Creative Commons Public Domain Dedication waiver (http://creativecommons.org/publicdomain/zero/1.0/) applies to the data made available in this article, unless otherwise stated in a credit line to the data. 


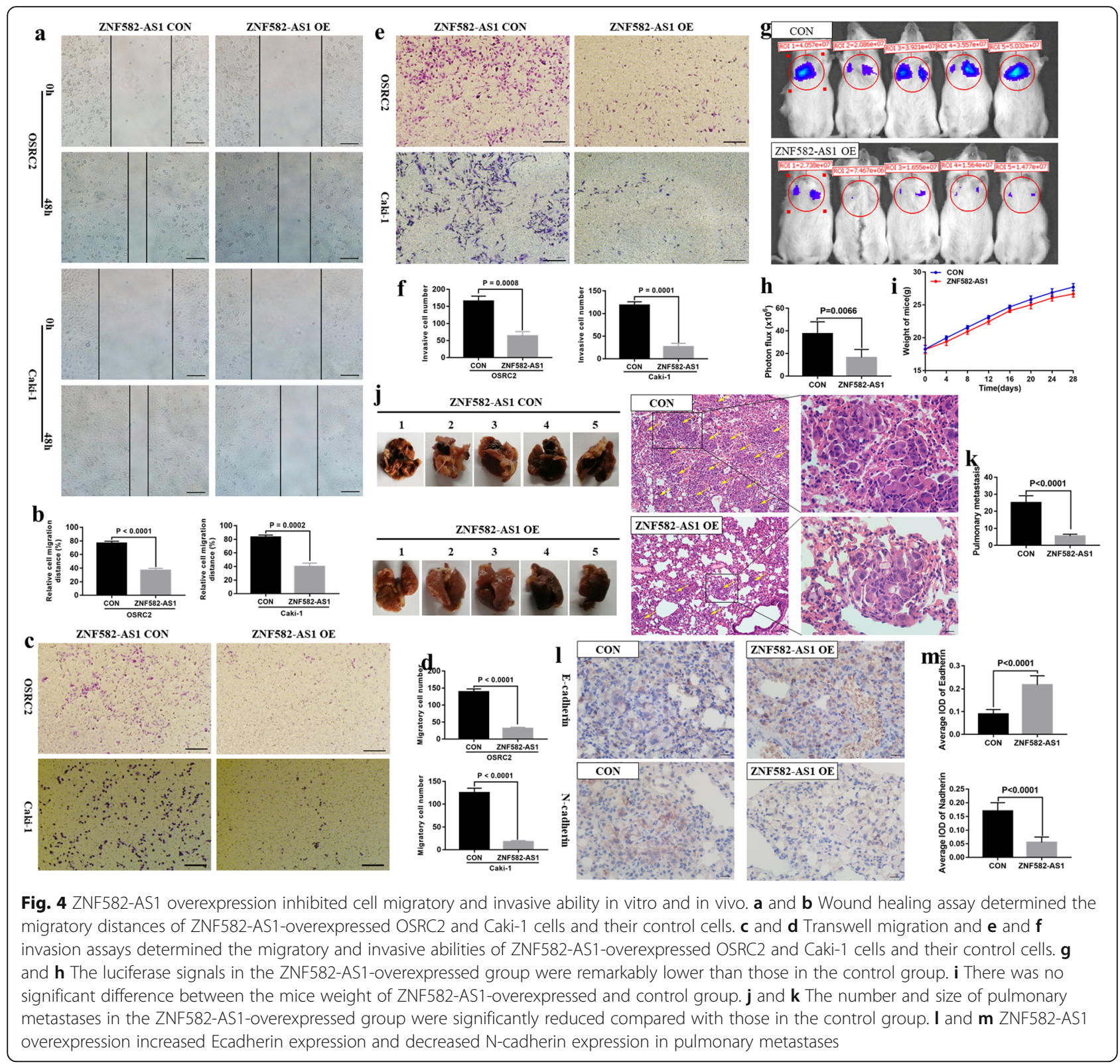

\section{Author details}

'Department of Urology, Peking University First Hospital, No. 8, Xishiku Street, Xicheng District, Beijing 100034, China. ${ }^{2}$ Hereditary Kidney Cancer Research Center, Peking University First Hospital, No. 8, Xishiku Street, Xicheng District, Beijing 100034, China. ${ }^{3}$ Institute of Urology, Peking University, Beijing 100034, People's Republic of China. ${ }^{4}$ National Urological Cancer Center, Beijing 100034, People's Republic of China.

Published online: 13 May 2021

\section{Reference}

1. Yang W, Zhang K, Li L, Xu Y, Ma K, Xie H, et al. Downregulation of IncRNA ZNF582-AS1 due to DNA hypermethylation promotes clear cell renal cell carcinoma growth and metastasis by regulating the N(6)-methyladenosine modification of MT-RNR1. J Exp Clin Cancer Res. 2021;40(1):92. https://doi. org/10.1186/s13046-021-01889-8. 